\title{
Conceptualizing Innovation Capabilities: A Contingency Perspective
}

\author{
Tor Helge Aas ${ }^{1}$ and Karl Joachim Breunig ${ }^{2}$
}

\begin{abstract}
Empirical research has confirmed that a positive relationship exists between the implementation of innovation activities and the future performance of organizations. Firms utilize resources and capabilities to develop innovations in the form of new products, services or processes. Some firms prove to be better at reproducing innovation success than others, and the capacity to do so is referred to as innovation capability. However, the term innovation capability is ambiguously treated in extant literature. There are several different definitions of the concept and the distinction between innovation capabilities and other types of capabilities, such as dynamic capabilities, is neither explicitly stated, nor is the relationship between the concept and other resource- and capability-based concepts within strategy theory established. Although innovation is increasingly identified as crucial for a firm's sustainable competitiveness in contemporary volatile and complex markets, the strategy-innovation link is underdeveloped in extant research. To overcome this challenge this paper raises the following research question: What type of innovation capabilities are required to innovate successfully? Due to the status of the extant research, we chose a conceptual research design to answer our research question and the paper contributes with a conceptual framework to discuss what innovation capabilities firms need to reproduce innovation success. Based on careful examination of current literature on innovation capability specifically, and the strategy-innovation link in general, we suggest that innovation capability must be viewed along two dimensions - innovation novelty and market characteristics. This framework enables the identification of four different contexts for innovation capabilities in a two-bytwo matrix. We discuss the types of innovation capabilities necessary within the four different contexts. This novel framework contributes to the understanding of the strategy-innovation link as well as clarifies the conceptual understanding of capabilities within the strategy literature and establishes the relationship between these structures and innovation management theory.
\end{abstract}

1 Tor Helge Aas, Associate Professor, School of Business and Law - University of Agder Gimlemoen 19, 4630, Kristiansand, Norway, e-mail: tor.h.aas@uia.no.

2 Karl Joachim Breunig, Professor, Oslo Business School - Oslo and Akershus University College, PB 4 St. Olavs PI., N-0130 Oslo, Norway, e-mail: karl.joachim.breunig@hioa.no. 
Keywords: conceptual framework; capabilities; innovation novelty; market characteristics; strategy-innovation link.

\section{INTRODUCTION}

Firms utilize their resources and capabilities for the development of innovations, such as new products, services or processes (Hill, Brandeau, Truelove \& Lineback, 2015). Empirical studies indicate that there is a positive relationship between the implementation of innovation activities and future performance (Bowen, Rostami \& Steel, 2010; Rubera \& Kirca, 2012). The resources and capabilities needed to succeed in innovation activities vary widely between firms. Some firms prove to be better at reproducing innovation success than others, and the capacity to do so can be framed as an innovation capability. Innovation capability is defined as a firm's ability to identify new ideas and transform them into new/improved products, services or processes that benefit the firm.

Current descriptions of innovation capabilities overlap with the notion of dynamic capabilities (Teece, 1997), making these concepts difficult to distinguish. Dynamic capabilities refer to a pervasive concept within the field of strategic management. The term 'dynamic capability' was coined by Teece et al. (1997) and is defined as "the firm's ability to integrate, build, and reconfigure internal and external competences to address rapidly changing environments (p. 516)". However, a thorough review by Barreto (2010) identified several other definitions of the concept that are frequently cited, and thus concluded that the conceptual underpinnings of dynamic capabilities are underdeveloped. Despite the identified conceptual ambiguities, dynamic capabilities are central to innovation strategy (Tidd, 2012). Moreover, current research also calls for an improved understanding of the link between strategy and innovation (Lightfoot \& Gebauer, 2011).

Conceptualizing innovation capabilities is a recently emerging complex field of study and the topic has attracted interest from a number of scholars (e.g. Forsman, 2011; Guan \& Ma, 2003; Hertog, van der Aa \& de Jong, 2010). However, there remains a lack of consensus in the literature and a pressing need to clarify what type of capabilities drive innovation (Lidija \& Robert, 2014), and how these capabilities are developed and utilized (Helfat \& Peteraf, 2003). This conceptual paper therefore, aims to synthesize the current understanding of innovation capability and provide a framework to discuss the type of innovation capabilities necessary for innovation success over time. The following research question is raised: What type of innovation capabilities are required to innovate successfully? 
The paper is divided into three sections. First, we map out the theoretical underpinnings of the resource- and capability-perspective of strategic management, and link these to innovation capability as addressed within the innovation management literature. Second, we present a conceptual research approach and suggest that the type of innovation capabilities required for success is related to two important contingency variables. Capability dynamics are contingent upon the degree of market changes - static as opposed to fast-moving. In our assessment of innovation management theory, we identify that organizational innovation processes are contingent upon the degree of novelty - incremental as opposed to radical. Therefore, we suggest a framework including four different contexts that emerge by utilizing these two contingency variables to construct a two-by-two matrix. Lastly, we utilize this framework to present a concluding discussion with key implications and limitations.

\section{THEORETICAL BACKGROUND}

Organizations must be able to manage change in an increasingly volatile and complex service eco-systems (Yoo \& Kim, 2015) to succeed in the contemporary globalized and hyper-velocity business environment (Crossan \& Apaydin, 2010; Francis \& Bessant, 2005). Dynamic capabilities, therefore, are central to innovation (Tidd, 2012), as they are linked to sustained competitiveness under these conditions (Eisenhardt, 2004). However, the link between a firm's strategic management of resources and capabilities that are heterogeneously distributed among firms and the ability to replicate innovation success over time has not yet been firmly established. It is therefore necessary to assess the theoretical underpinnings of the resource- and capability perspectives within strategic management, to better understand the concept of innovation capability.

\section{The theoretical underpinnings of resource and capability perspectives}

The resource-based view of the firm (RBV) is a popular strategic management perspective suggesting that very specific resources, competencies and capabilities are necessary to sustain a firm's competitive position (Barney, 1991; Penrose, 1959; Petraf, 1993; Spender, 1996; Wernerfelt, 1984). According to the RBV, it is the creation, ownership, management and deployment of intangibles, specifically knowledge and relationships, which explain variations in performance. In particular, intangibles that are valuable, rare, inimitable and non-substitutable, and therefore heterogeneously distributed, explain variation between firms. A firm must exploit and 
successfully deploy resources that competitors are not able to copy in order for resources to be of value. This perspective suggests that a key determinant of competitive advantage includes the internal organization of firms, and acts in conjunction with the external industry structure and positioning view of strategy as a key determinant of competitive advantage (Porter, 1980; 1985).

In order to extend the theory to incorporate external market variations Teece et al. (1997) coined the term dynamic capabilities. Teece et al. (1997, p. 517) state that "winners have been firms that can demonstrate timely responsiveness and rapid and flexible product innovation, coupled with the management capability to effectively coordinate and redeploy internal and external competences". Hence, the dynamic capabilities perspective is not only inward-looking in relation to the organization and its strategies but also incorporates the notion of innovation.

The core idea of the dynamic capabilities perspective is that sustained performance is achieved by aligning the organization with shifting external environmental demands by achieving evolutionary fitness, defined as "how well a dynamic capability enables an organization to make a living by creating, extending, or modifying its resource base" (Helfat et al., 2007, p. 120). By definition, therefore, dynamic capabilities involve adaptation and change because they build, integrate and reconfigure other resources and ordinary capabilities.

However, the dynamic capabilities perspective cannot fully explain how a firm uses resources and capabilities to create competitive advantage (Helfat \& Peteraf, 2003). Helfat (2003) distinguishes the terms resources and capabilities. Resource is an asset or input to production (tangible or intangible), while capability is the utilization of resources in a coordinated manner to achieve a goal. This distinction emphasizes that value does not arise from the possession of resources alone but includes the wise use of resources, and is linked to how resources are deployed, i.e. how they are combined within the firm. A firm must, therefore, continually develop expertise and innovations, and managers must possess entrepreneurial, in addition to managerial skills (Penrose, 1959). Thus, a capability, does not represent a single resource in the concert of other resources (e.g. financial assets, technology, manpower), but is a distinctive and superior method for the allocation of resources.

Related to the discussion about dynamic capabilities is the capabilitieslifecycle (CLC) perspective introduced by Helfat and Peteraf (2003) in order to formulate a dynamic resource-based view of the firm. The concept of CLC follows Wernerfelt's (1984) observation that products and resources are two sides of the same coin. Accordingly, Helfat and Peteraf (2003) suggest that capabilities, much like products, go through cycles of development, 
maturation and decline. The author suggests that both ordinary and dynamic capabilities are subject to these lifecycles.

The dynamic capabilities approach has extended the applicability of the resource-based view of strategic management to a dynamic market environment (Eisenhardt \& Martin, 2000). Faced with a dynamic market environment and uncertain market opportunities, a firm must build new skills and create new knowledge to enhance innovativeness and competitiveness (Cohen \& Levinthal, 1990; Kogut \& Zander, 1993). Capability adaptation is essential for long-term competitive advantage (Tallman, 2003). Dynamic capabilities give firms a sustained competitive advantage by avoiding the core rigidities which inhibit development, generate inertia and stifle innovation (Leonard-Barton, 1992). Accordingly, the main motivation behind the dynamic capabilities perspective is to explain how firms sustain their performance over time. Consequently, in order for firms to sustain their performance over time they must have the capacity to flexibly adapt - and the adaptation required is often related to the creation of new products, services or process (Hill et al., 2002). This is where the resource and capability perspective of strategic management overlap with ideas in innovation management, and when firms demonstrate that they have a capacity to replicate previous innovation success they are said to possess a certain innovation capability -also an ambiguous term in existing research.

\section{Innovation capability}

A firm's 'innovation capability' can be understood as the potential to innovate (Saunila \& Ukko, 2012), or more specifically the "ability to continuously transform knowledge and ideas into new products, processes and systems for the benefit of the firm and its stakeholders" (Lerro, Linzalone \& Schiuma, 2009 , p. 11). It has been suggested that innovation capabilities are so-called higher-order capabilities or "the ability to mould and manage multiple capabilities" (Lawson \& Samson, 2001, p. 380). Firms that possess these capabilities have "the ability to integrate key capabilities and resources of their firm to successfully stimulate innovation" (Lawson \& Samson, 2001, p. 380). Accordingly, attempts to define innovation capability have overlapped with the theory of dynamic capabilities. In addition, within the conceptualization of innovation capability is the idea that capability is linked to renewal and performance of a firm over time, especially with changing markets and the idea that it is necessary for a firm to be flexible and adapt services and products offered. Moreover, innovation capability includes a combination and orchestration of resources to maintain fitness along with external changes. Again, the above definition appears to overlap with dynamic innovations; 
however, innovation capability focuses more directly on the firm's ability to change its offerings, while dynamic capability emphasizes environmental fitness as an indication of performance (Helfat, et al., 2007).

A recent bibliometric study presented by Narcizo et al., (2017) revealed a total of 19 different definitions for 'innovation capability', and concluded that the variability in descriptions of the term make a unified definition difficult.

Innovation capabilities have been divided into different categories by different researchers. For example, Lawson and Samson (2001) suggested that innovation capabilities consist of seven elements (vision, competence base, organizational intelligence, creativity, idea management, organizational structures, culture and climate, and management of technology). Terziovski (2007) on the other hand, suggested just two categories: collaboration and knowledge transfer. Den Hertog et al. (2010) identified six dynamic service innovation capabilities (signalling used needs and technological options, conceptualizing, (un)bundling, (co)producing and orchestrating, scaling and stretching, and learning and adapting), arguing for innovation capability as contingent upon the context (i.e. whether the innovation is aiming at product or service improvements).

Consequently, the different approaches described above, and the different contexts from which innovation capabilities can be viewed may account for the ambiguity of definitions in the literature.

\section{A contingency perspective on innovation capability}

Several authors have suggested that innovation capabilities are dependent upon context. For example, Francis (2000) suggested that innovation capabilities "may not be unitary and may vary between organizational levels, configurations, national or firm-specific cultures, distinctive strategies, different threat levels, technological complexity or other factors" (p. 106). In other words, there are a number of contingency variables that may affect the type of innovation capabilities required. Variables of particular interest in recent literature include industry type (e.g., Forsman, 2011), geographical area or region (e.g., Guan \& Ma, 2003), firm size (e.g., Keskin, 2006), and innovation type (e.g., den Hertog et al., 2010).

The degree of novelty and market characteristics are two contingency variables that have proven to be particularly helpful in studies related to innovation management as well as strategic management. One way to classify innovation is through different degrees of novelty (Dewar \& Dutton, 1986). On one end of the spectrum are firms with incremental innovations in the form of minor improvements of existing products, services or processes (Ettlie, 1983). On the other end of the spectrum are firms with radical innovations 
in the form of considerable transformations of existing products, services or processes (Chandy \& Tellis, 2000). Results of empirical studies indicate that radical innovation processes are different from more incremental innovation processes (e.g., Sandberg \& Aarikka-Stenroos, 2014). The type of innovation capabilities required for success depends on the degree of novelty. For example, innovation capabilities that are needed to carry out radical innovation processes are different from those needed to carry out incremental innovation processes. In general this idea is also supported by empirical work (e.g. Forés \& Camisón, 2016; Subramaniam \& Youndt, 2005).

According to Teece et al. (1997), the RBV is only applicable to sustained competitive advantage in static market environments and not in changing and fast-moving markets. From this we could also expect that the innovation capabilities required in a static market environment would be different from the capabilities required in a more changing and fast moving market environment. This idea is also supported with some empirical studies. Carbonell and Rodriguez (2006), for example, found that innovation speed is contingent on the level of market uncertainty. However, there is some discrepancy in this area of research and as such, how the required innovation capabilities vary between different market characteristics is not well understood.

The existing literature is lacking discussion on how different combinations of the two contingency variables (novelty and market characteristics) affect required innovation capabilities. The current paper aims to address this gap in knowledge. Four contexts emerge from the two contingency variables: 1) static market with incremental innovation, 2) static market with radical innovation, 3) changing and fast-moving market with incremental motivation, and 4) changing and fast-moving market with radical innovation.

The four contexts are illustrated in Figure 1.

Figure 1 shows the core innovation capabilities hypothesized to be necessary in each context. The following is a discussion of the types of innovation capabilities required in the four different contexts in more detail. While there are many factors involved in innovation capabilities, such as vision, creativity, idea management, organizational structures and others (Lawson \& Samson, 2001), we focus here on knowledge and knowledge transfer since they have previously been proposed as the main elements of innovation capabilities (Terziovski, 2007). 


\begin{tabular}{|c|c|c|c|}
\hline & \multicolumn{2}{|c|}{$\begin{array}{c}\text { Market } \\
\text { characteristics }\end{array}$} \\
\hline & & Static & Fast moving \\
\hline \multirow{2}{*}{$\begin{array}{l}\text { Innovation } \\
\text { novelty }\end{array}$} & Incremental & $\begin{array}{l}\text { Core innovation } \\
\text { capability: } \\
\text { Ability to utilize existing } \\
\text { organizational and social } \\
\text { capital to improve existing } \\
\text { products, services and } \\
\text { processes }\end{array}$ & $\begin{array}{l}\text { Core innovation } \\
\text { capability: } \\
\text { Ability to change and } \\
\text { reconfigure organizational and } \\
\text { social capital needed to adapt } \\
\text { existing products, services and } \\
\text { processes to new market } \\
\text { demands }\end{array}$ \\
\hline & Radical & $\begin{array}{l}\text { Core innovation } \\
\text { capability: } \\
\text { Ability to utilize existing } \\
\text { human and social capital to } \\
\text { develop new products, } \\
\text { services and processes }\end{array}$ & $\begin{array}{l}\text { Core innovation } \\
\text { capability: } \\
\text { Ability to change and } \\
\text { reconfigure human and social } \\
\text { capital needed to develop new } \\
\text { products, services and processes } \\
\text { to new market demands }\end{array}$ \\
\hline
\end{tabular}

Figure 1. Four contexts for innovation capability based on degree of innovation novelty and market characteristics

\section{Context 1 - Static market and incremental innovations}

In a static market, a successful and established firm does not need to search for opportunities outside its existing market. Innovation in this context is focused on improving products and services the firm already delivers to its customers, as well as improving the production processes associated with these products and services. The firm in this case, must understand how existing customers perceive services and products and to what degree existing production processes are efficient. According to the findings of Subramaniam and Youndt (2005), knowledge in the form of organizational capital and in the form of social capital is necessary in these processes.

In Context 1, organizational capital refers to "institutionalized knowledge and codified experiences residing within and utilized through databases, patents, manuals, structures, systems and processes" (Subramaniam \& Youndt, 2005, p. 451). Thus, organizational capital includes codified preserved knowledge related to how activities within the firm are carried out and to what degree these approaches have proven to be successful. In incremental innovation processes this prevailing knowledge is typically reinforced (Martin \& Mitchell, 1998) leading to a path-dependent development of products, services and processes (Danneels, 2002).

In addition to organizational capital, social capital is necessary in a static market with incremental innovation. Social capital may be defined as "the knowledge embedded within, available through and utilized by interactions among individuals and their networks of interrelationships" (Subramaniam 
\& Youndt, 2005, p. 451). Research has indicated that interactions between employees and customers are beneficial in identifying how existing products and services may be improved (Laursen, 2011). Likewise, interactions between employees and suppliers are often important in incremental product-, service- and process- innovation (Song \& Thieme, 2009). Lastly, incremental innovation processes benefit from interactions between employees that collaborate in teams since such collaboration improves how codified knowledge is updated (Subramaniam \& Venkatraman, 2001).

Thus, to summarize the innovation capabilities necessary for success in Context 1 (static market/incremental innovation), a firm must both create knowledge internally and utilize external knowledge (Forés \& Camisón, 2016). In this case, external knowledge flows from customers and suppliers to employees. However, knowledge from external actors outside the value chain, such as research institutions, universities, competing firms and consultancy firms, are not relevant in this context. The static market characteristics of Context 1 also imply that the firm does not need to change and re-configure resources and capabilities. Thus, dynamic capabilities as defined by Teece et al., (1997) and Teece (2014) play a limited role in this context.

\section{Context 2 - Static market and radical innovations}

As in Context 1, the market is static in Context 2 and as such, it is not necessary for an established firm to search for opportunities outside the existing market. In Context 2, innovation is about radically transforming the products and services a firm already delivers to its customers, as well as radically transforming the production processes associated with these products and services. Human capital is defined as "the knowledge, skills and abilities residing with and utilized by individuals" (Subramaniam \& Youndt, 2005, p. 451). Radical innovation processes require "questioning prevailing norms and looking for fundamentally different solutions to existing problems" (Subramaniam \& Youndt, 2005, p. 454). According to the findings of Subramaniam and Youndt (2005), the interaction of knowledge gained from human capital and knowledge gained from social capital positively influence the ability to carry out radical innovation processes. Organizational capital, on the other hand, plays a limited role in these processes. Creative and knowledgeable employees that are able to question existing solutions and routines and come up with or identify radically new ideas are needed for successful radical innovation (Tushman \& Anderson, 1986).

Empirical research has indicated that creative and knowledgeable employees must interact with other employees within the firm during the radical innovation process (Cuevas-Rodríguez, Cabello-Medina \& Carmona- 
Lavado, 2014). Indeed, Martinkenaite and Breunig (2016) emphasize the role of individual employee learning in the organizational absorption process for successful learning capability and absorption capacity.

In addition to internal interactions within the firm, external interactions within the value chain are necessary for successful radical innovation processes (Soosay, Hyland \& Ferrer, 2008). Traditional marketing research may not suffice since potential customers may have no prior experience with the planned innovations. However a firm may rely on design thinking (Brown, 2009; Kimbell, 2011; Lockwood, 2010) principles and encourage customercentricity in the innovation and development process to allow for early feedback and experiences from the market.

External actors from outside the value chain are also beneficial to the radical innovation process. The findings of Belderbos, Carree, and Lokshin (2004), for example, confirmed that universities as well as competitors are important sources of knowledge during radical innovation processes. Thus, in Context 2 the firm needs a more developed absorptive capacity than in Context 1 . The firm must identify, understand, obtain and use knowledge from a wide range of external organizations such as research institutions, universities, competitors, customers, and suppliers. The market environment in Context 2 is static and therefore, as in Context 1 , the ability to reconfigure and change resources and capabilities is not necessary. The core innovation capabilities in Context 2 are associated with the firm's ability to build, buy, or source 'advanced' resources and exploit them.

\section{Context 3 - Fast moving market and incremental innovations}

The market environment in Context 3 is unstable and fast-moving and consequently, an established firm must continuously search for new opportunities both within and outside the existing market. Innovation in this context requires both the improvement of existing products, services and processes and the alignment of products and services with new markets and new customer needs. The core capabilities discussed in Context 1 are also relevant in Context 3 (see Figure 1). Thus, the firm must utilize organizational and social capital to succeed with incremental innovations.

However, in Context 3 the use of existing organizational and social capital is not sufficient. Due to a fast-moving market, a firm's existing resources, for example in the form of organizational and social capital, become less relevant. The following is an example to illustrate this concept: An electronics firm sells products to the oil industry, but due to reduced demand from the oil industry the firm must find new markets. Therefore, the firm decides to align and adjust their products and sell them to car manufacturers. This innovation is 
considered incremental since the changes in the existing products may be minor (Ettlie, 1983). In this example, existing organizational and social capital may be insufficient during the innovation process. The electronic firm's social capital (interactions between employees within the firm and employees in the oil industry) is no longer relevant and the firm must build new social capital consisting of interactions with employees in the car industry. Likewise, organizational capital must be altered. The car manufacturers for example, may require that the firm implement a different production and quality system that aligns with standards in the car industry.

Consequently, success in Context 3 requires that the firm changes and reconfigures organizational and social capital and utilize new resources that emerge from this reconfiguration. According to Teece (1997), this ability is considered a dynamic capability.

\section{Context 4 - Fast moving market and radical innovations.}

As with Context 3, in Context 4 the market is unstable and fast-moving and therefore, established firms must continuously search for new opportunities both within and outside the existing market. Innovation in Context 4 however, is radical and involves developing entirely new products, services and processes that fulfil emerging needs of existing, as well as new customer segments. The core capabilities discussed in Context 2 are also relevant in context 4 (see Figure 1 ) in that the firm must utilize human and social capital to succeed with radical innovations.

However, as in Context 3, the ability to utilize existing resources is insufficient. The development of radically new products and services to new markets and customers in a fast-moving market may require a different human and social capital than that required in a stable market. In this context, the firm must adapt technical fitness to that of competitors and the preferences of the new customers (Helfat et al. 2007). Thus, in Context 4 a firm must change and reconfigure existing human and social capital and utilize this knowledge during the radical innovation process. Context 4 most closely resembles the high velocity (Eisenhardt \& Martin 2000) and rapidly changing markets as recorded in extant dynamic capability literature (Teece, 2014) and as such, the ability to reconfigure human and social capital is considered a dynamic capability (1997).

\section{CONCLUDING DISCUSSION}

Due to the present ambiguities of the conceptualization of innovation capabilities (Lidija \& Robert, 2014), this paper aimed to discuss the types 
of innovation capabilities that are necessary for successful innovation performance. Moreover, due to the overlap of related concepts from the strategy and innovation literature, such as absorptive capacity (Cohen \& Levinthal, 1990) and dynamic capabilities (Eisenhardt \& Martin, 2000; Teece, Pisano \& Shuen, 1997), the current paper also sought to provide an improved understanding of the strategy-innovation link.

The extant research includes a variety of approaches to innovation capability, with a wide variation in definitions and conceptualizations. Our assessment of the extant research literature revealed that in particular, two contingency variables could account for different approaches to innovation capability, as variation in definitions and conceptualizations might be based on an attempt to frame and define innovation capability within different contexts, without explicating how the understanding of the concept might be contingent on these contextual differences. Therefore, we suggest that the innovation capabilities necessary for success are contingent upon innovation novelty and market characteristics. The contexts that emerge from the combination of these two contingency variables clarify some of the discrepancies in the literature.

The discussion demonstrates that the knowledge and absorptive capacity necessary to carry out innovation varies between the contexts. For example, organizational capital is particularly important in incremental innovation contexts, while human capital is more important in radical innovation contexts. The capacity to understand external research based knowledge is more important in radical innovation contexts than in incremental innovation contexts.

The information presented contributes to the understanding of the relationship between innovation capabilities and dynamic capabilities. Dynamic capabilities are required for successful innovation in fast-moving markets, but have a more limited role in the context of static markets. There is therefore both an overlap and a separation between the concepts of innovation capabilities and dynamic capabilities, and as such, our framework (Figure 1) identifies distinctions between the related concepts of innovation capability, absorptive capacity and dynamic capability. This framework goes beyond the existing definition that innovation capability focuses more directly on the ability to change offerings, as opposed to dynamic capability that emphasizes environmental fitness. The presented framework illustrates that innovation capability is present both in contexts that require (Contexts 3 and 4 ) and contexts that do not require (Contexts 1 and 2 ) dynamic capability.

The suggested conceptual framework can be used by practitioners to identify the innovation capabilities an organization is able to build through their activities. Subsequently, this assessment can be used by managers 
to determine the type of innovation capabilities they need focus on to successfully implement their innovation strategies.

It should be noted that the study has limitations and that the results should be used with some caution due to the conceptual nature of the study. Further empirical research is needed to verify whether conclusions reached may be observed in a true business environment. The results of the conceptual discussion suggest that future empirical research employs a contingency approach when innovation capabilities are examined. Moreover, further research should explore other potential contingencies, such as industry, geographical area or region, firm size, and innovation type, to further the understanding of how contingencies affect the strategy-innovation link in general, and innovation capability in particular.

\section{References}

Barney, J. B. (1991). Firm resources and sustained competitive advantage. Journal of Management, 17(1), 99-120.

Barreto, I. (2010). Dynamic capabilities: A review of past research and an agenda for the future. Journal of Management, 36(1), 256-280.

Belderbos, R., Carree, M., \& Lokshin, B. (2004). Cooperative R\&D and firm performance. Research Policy, 33(10), 1477-1492.

Bowen, F. E., Rostami, M., \& Steel, P. (2010). Timing is everything: A metaanalysis of the relationships between organizational performance and innovation. Journal of Business Research, 63(11), 1179-1185.

Brown, T. (2009). Change by Design: How Design Thinking Transforms Organizations and Inspires Innovation. HarperCollins.

Chandy, R. K., \& Tellis, G. J. (2000). The incumbent's curse? Incumbency, size and radical product innovation. Journal of Marketing, 64(3), 1-17.

Cohen, W. M., \& Levinthal, D. A. (1990). Absorptive capacity: A new perspective on learning and innovation. Administrative Science Quarterly, 35(1), 128152.

Crossan, M. M., \& Apaydin, M. (2010). A multi-dimensional framework of organizational innovation: A systematic review of the literature. Journal of Management Studies, 47(6), 1154-1191.

Cuevas-Rodríguez, G., Cabello-Medina, C., \& Carmona-Lavado, A. (2014). Internal and external social capital for radical product innovation: Do they always work well together? British Journal of Management, 25(2), 266-284.

Danneels, E. (2002). The dynamics of product innovation and firm competences. Strategic Management Journal, 23(12), 1095-1121.

Dewar, R. D., \& Dutton, J. E. (1986). The adoption of radical and incremental innovations: An empirical analysis. Management Science, 32(6), 14221433. 
Eisenhardt, K. M. (2004). Speed and Strategic Change: How managers accelerate decision making. In R. Katz (Ed.), The human side of managing technological innovation (pp. 508-518). New York: Oxford University Press.

Eisenhardt, K. M., \& Martin, J. A. (2000). Dynamic capabilities: Why are they? Strategic Management Journal, 21(10/11), 1105-1121.

Ettlie, J. E. (1983). Organizational policy and innovation among suppliers to the food processing sector. Academy of Management Journal, 26(1), 27-44.

Forés, B., \& Camisón, C. (2016). Does incremental and radical innovation performance depend on different types of knowledge accumulation capabilities and organizational size? Journal of Business Research, 69(2), 831-848.

Forsman, H. (2011). Innovation capacity and innovation development in small enterprises. A comparison between the manufacturing and service sectors. Research Policy, 40(5), 739-750.

Francis, D., \& Bessant, J. (2005). Targeting innovation and implications for capability development. Technovation, 25(3), 171-183.

Francis, D. L. (2000). Assessing and improving innovation capability in organisations. (Doctoral dissertation), University of Brighton.

Guan, J., \& Ma, N. (2003). Innovative capability and export performance of Chinese firms. Technovation, 23(9), 737-747.

Helfat, C. E. (2003). Stylized facts regarding the evolution of organizational resources and capabilities. In C. E. Helfat (Ed.), The SMS Blackwell Handbook of Organizational Capabilities: Emergence, Development, and Change (pp. 1-14). Oxford: Blackwell Publishing.

Helfat, C. E., Finkelstein, S., Mitchell, W., Peteraf, M. A., Singh, H., Teece, D., \& Winter, S. G. (Eds.). (2007). Dynamic Capabilities: Understanding Strategic Change in Organizations. Malden, MA: Blackwell Publishing.

Helfat, C. E., \& Peteraf, M. A. (2003). The dynamic resource-based view: Capability lifecycles. Strategic Management Journal, 24(10), 997-1010.

Hertog, P. d., van der Aa, W., \& de Jong, M. W. (2010). Capabilities for managing service innovation: Towards a conceptual framework. Journal of Service Management, 21(4), 490-514.

Hill, A. V., Collier, D. A., Froehle, C. M., Goodale, J. C., Metters, R. D., \& Verma, R. (2002). Research opportunities in service process design. Journal of Operations Management, 20(2), 189-202.

Hill, L. A., Brandeau, G., Truelove, E., \& Lineback, K. (2015). The capabilities your organization needs to sustain innovation. Harvard Business Review (January 14).

Keskin, H. (2006). Market orientation, learning orientation, and innovation capabilities in SMEs: An extended model. European Journal of innovation Managemen, 9(4), 396-417.

Kimbell, L. (2011). Rethinking design thinking: Part I. Design and Culture, 3(3), 285-306. 
Kogut, B., \& Zander, U. (1993). Knowledge of the firm and the evolutionary theory of the multinational corporation. Journal of International Business Studies, 24(4), 625-645.

Laursen, K. (2011). User-producer interaction as a driver of innovation: Costs and advantages in an open innovation model. Science and Public Policy, 38(9), 713.

Lawson, B., \& Samson, D. (2001). Developing innovation capability in organisations: A dynamic capabilities approach. International Journal of Innovation Management, 5(3), 377-400.

Leonard-Barton, D. (1992). Core-capabilities and core rigidities: A paradox in managing new product development. Strategic Management Journal, 13, 111-125.

Lidija, B., \& Robert, D. H. (2014). Dynamic capabilities vs. innovation capability: Are they related? Journal of Small Business and Enterprise Development, 21(3), 368-384.

Lightfoot, H. W., \& Gebauer, H. (2011). Exploring the alignment between service strategy and service innovation. Journal of Service Management, 22(5), 664-683.

Lockwood, T. (2010). Design Thinking. Integrating Innovation, Customer Experience, and Brand Value. New York: Allworth Press.

Martin, X., \& Mitchell, W. (1998). The influence of local search and performance heuristics on new design introduction in a new product market. Research Policy, 26(7), 753-771.

Martinkenaite, I., \& Breunig, K. J. (2016). The emergence of absorptive capacity through micro-macro level interactions. Journal of Business Research, 69(2), 700-708.

Narcizo, R.B., Canen, A.G., \& Tammela, I. (2017). A conceptual framework to represent the theoretical domain of "innovation capability" in organizations. Journal of Entrepreneurship, Management and Innovation, 13(1), 145-164.

Penrose, E. T. (1959). The Theory of the Growth of the Firm. New York: John Wiley and Son.

Petraf, M. A. (1993). The cornerstones of competitive advantage: A resourcebased view. Strategic Management Journal, 14(3), 179-191.

Porter, M. E. (1980). Competitive Strategy. New York: Free Press.

Porter, M. E. (1985). Competitive Advantage: Creating and Sustaining Superior Performance. New York: The Free Press.

Rubera, G., \& Kirca, A. H. (2012). Firm innovativeness and its performance outcomes: A meta-analytic review and theoretical integration. Journal of Marketing, 76(3), 130-147.

Sandberg, B., \& Aarikka-Stenroos, L. (2014). What makes it so difficult? A systematic review on barriers to radical innovation. Industrial Marketing Management, 43(8), 1293-1305. 
Song, M., \& Thieme, J. (2009). The role of suppliers in market intelligence gathering for radical and incremental innovation. Journal of Product Innovation Management, 26(1), 43-57.

Soosay, C. A., Hyland, P. W., \& Ferrer, M. (2008). Supply chain collaboration: Capabilities for continuous innovation. Supply Chain Management: An International Journal, 13(2), 160-169.

Spender, J.-C. (1996). Making knowledge the basis of a dynamic theory of the firm. Strategic Management Journal, 17(Winter Special Issue), 45-62.

Subramaniam, M., \& Venkatraman, N. (2001). Determinants of transnational new product development capability: Testing the influence of transferring and deploying tacit overseas knowledge. Strategic Management Journal, 22(4), 359-378.

Subramaniam, M., \& Youndt, M. A. (2005). The influence of intellectual capital on the types of innovative capabilities. Academy of Management Journal, Vol. 48, (No. 3, ), 450-463.

Tallman, S. B. (2003). Dynamic Capabilities: Oxford: Oxford University Press.

Teece, D. J. (2014). The foundations of enterprise performance: Dynamic and ordinary capabilities in an (economic) theory of firms. The Academy of Management Perspectives, 28(4), 328-352.

Teece, D. J., Pisano, G., \& Shuen, A. (1997). Dynamic capabilities and strategic management. Strategic Management Journal, 18(7), 509-534.

Terziovski, M. (2007). Building Innovation Capability in Organizations: An International Cross-case Perspective. London: Imperial College Press.

Tidd, J. (2012). From Knowledge Management to Strategic Competence: Assessing Technological, Market and Organizational Inoovatation. London: Imperial College Press.

Tushman, M. L., \& Anderson, P. (1986). Technological discontinuities and organizational environments. Administrative Science Quarterly, 31, 439465.

Wernerfelt, B. (1984). Resource-based view of the firm. Strategic Management Journal, 5(2), 171-180.

Yoo, Y., \& Kim, K. (2015). How Samsung became a design powerhouse. Harvard Business Review, 93(9), 72-12. 


\begin{abstract}
Polish)
Badania empiryczne potwierdziły istnienie pozytywnych relacji między realizacja działań innowacyjnych a przyszłymi wynikami organizacji. Firmy wykorzystujq zasoby i możliwości do opracowywania innowacji w postaci nowych produktów, usług lub procesów. Niektóre firmy okazujq się lepsze w odtworzeniu sukcesu innowacyjnego niż inne, a zdolność do tego określana jest jako zdolność do innowacji. Jednak termin ten nie jest jednoznacznie traktowany w literaturze. Istnieje kilka różnych definicji pojęcia, a rozróżnienie między zdolnościami innowacyjnymi a innymi rodzajami zdolności, takimi jak zdolności dynamiczne, nie zostało jednoznacznie określone, ani też zależności między tym pojęciem a innymi koncepcjami opartymi na zasobach i zdolnościach w teorii strategii. Chociaż zdolność do innowacji jest coraz bardziej identyfikowana jako kluczowa dla trwałej konkurencyjności przedsiębiorstwa we współczesnych, niestabilnych i złożonych rynkach, zwiqzek strategia - innowacje jest słabo rozwinięty w prowadzonych badaniach. Aby przezwyciężyć to wyzwanie, niniejszy artykuł podnosi następujqce pytanie badawcze: Jaki rodzaj zdolności innowacyjnych jest potrzebny do pomyślnego wprowadzenia innowacji? Biorqc pod uwagę istniejqce badania wybraliśmy konceptualny projekt badawczy po to, aby odpowiedzieć na nasze pytanie badawcze. W artykule uwzględniono ramy pojęciowe, aby omówić, jakie zdolności innowacyjne firmy musza posiadać, aby odtworzyć sukces innowacyjny.

Biorq̨c pod uwagę dokładne zbadanie obecnej literatury dotyczącej zdolności innowacyjnych oraz powiqzania strategia-innowacje, sugerujemy, aby zdolności innowacyjne rozpatrywać $w$ dwóch wymiarach - innowacyjności i cech rynkowych. Te ramy umożliwiajq identyfikację czterech różnych kontekstów zdolności innowacyjnych w matrycy dwa na dwa. Omawiamy rodzaje innowacji, które sq niezbędne w czterech różnych kontekstach. Te nowe ramy przyczyniajq się do zrozumienia powiqzania strategiczno-innowacyjnego, a także wyjaśniajq pojęcie zdolności w literaturze strategicznej i ustanawia zwiq̨zek między tymi strukturami a teoriq zarzq̨dzania innowacjami.
\end{abstract}

Słowa kluczowe: ramy koncepcyjne; zdolności; nowość; innowacyjność; cechy rynkowe; powiqzania strategiczno-innowacyjne. 


\section{Biographical notes}

Tor Helge Aas is an Associate Professor at the School of Business and Law at the University of Agder. He gained his Ph.D. in Strategy and Management from the Norwegian School of Economics. His research concentrates on topics such as 1) innovation processes and capabilities, 2) collaboration for innovation, 3) management control of innovation, and 4) the organizational effects of innovation. Contact: tor.h.aas@uia.no.

Karl Joachim Breunig is a Full Professor of Strategic Management at the Oslo Business School, Oslo and Akershus University College. He received his Ph.D. from the BI Norwegian Business School, and holds an MSc from the London School of Economics. Prof. Breunig's research concentrates on topics such as service innovation and digitalization in professional service firms, as well as strategic management, measurement and internationalization of knowledge work. Contact: karl.joachim.breunig@hioa.no. 